\title{
STORYTELLING, O LIMIAR DA PUBLICIDADE ILÍCTA NO ÂMBITO DO DIREITO DO CONSUMIDOR
}

\author{
STORYTELLING, THE THRESHOLD OF ILLEGAL ADVERTISING ON \\ CONSUMER RIGHTS UNDER
}

\author{
${ }^{1}$ Josinaldo Leal de Oliveira \\ 2Thyago Cezar
}

\begin{abstract}
RESUMO
Compreender o sistema de controle da publicidade no direito do consumidor deve ser uma preocupação do operador do direito, haja a vista o poder do fenômeno publicidade frente a um sujeito vulnerável: o consumidor. Cada dia mais as empresas têm usado técnicas de marketing e publicidade para apresentar seus produtos ao mercado consumidor, e atualmente uma técnica que vem sendo muito utilizada é o storytelling, porém, está técnica deve obedecer alguns parâmetros sob pena de levar o consumidor ao erro. O presente trabalho demonstra expressiva utilidade jurídica, na medida que apresenta uma análise jurídica de tema pouco explorado pela doutrina.
\end{abstract}

Palavras-chave: Storytelling, Publicidade, Publicidade enganosa, Direito do consumidor

\begin{abstract}
Understanding the advertising control system on consumer rights should be a concern of the operator's right, there is a view of the power of the front advertising phenomenon to a vulnerable subject: the consumer. Every day more companies have used marketing and advertising techniques to present their products to the consumer market, and currently a technique that has been widely used is the storytelling, however, this technique must meet certain parameters otherwise lead the consumer into error. This study demonstrates significant legal value, in that it presents a legal analysis of the issue little explored by the doctrine.
\end{abstract}

Keywords: Storytelling, Advertising, Misleading publicity, Consumer law

\footnotetext{
${ }^{1}$ Doutor em Ciências Jurídicas e Sociais pela Universidad del Museo Social Argentino - UMSA, Buenos Aires (Argentina). Professor pela Faculdade Anisio Teixeira - FAT, Bahia (Brasil). E-mail: leal.mla@gmail.com

${ }^{2}$ Especialização em Direito Processual Civil pela Universidade Anhanguera - Uniderp - UNIDERP, Mato Grosso do Sul (Brasil). E-mail: thyago@limaecezar.com.br
} 


\section{INTRODUÇÃO}

A publicidade é um fenômeno sempre presente na sociedade e no mercado, apresentando papel relevante em diversas etapas da economia, sendo, sem dúvida, um elemento importante para o desenvolvimento das sociedades.

Diante desse cenário de destaque é evidente que o emprego das diversas técnicas que a envolve deve ser visto com cautela, principalmente quando tem em seu bojo de apresentação um destinatário específico e vulnerável, como é o caso do consumidor.

O universo da publicidade apresenta-se de forma bem nítida pelo emprego de diversas técnicas usuais, por serem, inclusive, facilmente perceptíveis pelo mercado. Contudo, a peculiaridade desse fenômeno denominado publicidade ainda tem muito o que se evidenciar aos olhos dos consumidores, de forma que a ciência do direito e em especial do ramo do direito do consumidor, não pode se furtar de analisar contornos da ciência da comunicação que são capazes de alcançar os consumidores.

Os profissionais da publicidade identificaram que para alcançar o êxito do seu mister, o desenvolvimento de suas criatividades deveriam nortear por novas técnicas capazes de potencializar no mundo mercadológico o induzimento dos consumidores ao consumo, utilizando dentre outras técnicas para a divulgação da mensagem publicitária o storytelling.

Não há nada de inusitado em falar sobre storytelling. Porém, o presente escrito visa analisar a capacidade do storytelling influenciar o consumidor em atos de consumo.

É fato que a prática de storytelling tem sido cada vez mais corriqueira em mensagens publicitárias e que muitas delas apresentam conotação ilícita, para fins do Código de Defesa do Consumidor, ora por serem classificadas como enganosas, ora por serem manifestamente abusivas. Percebe-se que cada vez mais um número expressivo de consumidores são cativados e influenciados em atos de consumo em razão da prática do storytelling, o que precisa ser investigado pelo direito do consumidor. 
Assim, esse texto apresenta como objetivo verificar o storytelling junto ao fenômeno da publicidade sob a perspectiva do Direito do Consumidor.

Dessa forma, o presente escrito navega em torno dos seguintes questionamentos: O que é o storytelling? Como essa técnica se apresenta no âmbito do Direito do Consumidor? E por fim, é possível configurar uma mensagem publicitária como ilícita frente ao direito do Consumidor em razão do emprego do storytelling?

Para melhor analisar esses questionamentos, é preciso compreender a técnica do storytelling e o seu enquadramento dentro da sistemática do Direito do Consumidor.

\section{NOÇÕES PROPEDÊUTICAS}

Antes de tocarmos em um dos temas centrais deste trabalho, o storytelling, nos sentimos no dever de fazer uma brevíssima pausa, e discorrer sobre o termo comunicação.

A palavra comunicação tem sua origem no latim "communicatio", tendo como sua tradução literal parecido com "tornar comum", porém foi atribuído o significado de informação; participação; aviso transmissão; notícia; passagem; ligação; convivência, dentre outros significados como demonstra o dicionário Priberam da Língua Portuguesa.

A palavra comunicação pode levar a caminhos infinitos de significados. Ela alcança uma multiplicidade de sentidos. As tentativas de definí-la ocuparam diferentes dimensões no mundo do saber, há quem arrisque dizer que tudo é comunicação. Nesse estudo, o interesse está, precisamente, nas contribuições teóricas que vêm refletindo sobre a comunicação entre as pessoas e seus meios, na sua dimensão interpessoal e coletiva. Comunicação esta que, através do uso da palavra, estruturadora da linguagem, por sua vez concretizadora do discurso, funcionou como um fio condutor para a afirmação da humanidade como um grupo de animais que sente, pensa, intercambia subjetividades, age e reage na relação com o outro e com a natureza, formando uma teia de pensamentos e acontecimentos construída entre consensos e conflitos. O seu desenvolvimento, da oralidade a instrumentalização técnica, confunde-se com a luta da humanidade para sobreviver, dominar a natureza, construir conhecimentos e por expandir-se. Portanto, a comunicação está intrinsecamente ligada às relações de poder estabelecidas, gerando não poucas vezes a in-comunicação. (GOMES, 2007, p. 25)

Em sequência, para que a comunicação possa existir, temos que condensar as ideias e expressá-las através de uma linguagem, que seria a codificação da comunicação.

A linguagem é tão antiga quanto a consciência - a linguagem é a consciência real, prática, que existe também para os outros homens e que, assim existe igualmente para mim; e a linguagem surge como a consciência da incompletude, da necessidade 
dos intercâmbios com outros homens. Onde existe uma relação, ela existe por mim. O animal não se 'relaciona' com coisa alguma; simplesmente não se relaciona. [...] A consciência, consequentemente, desde o início é um produto social, e o continuará sendo enquanto existirem homens. (MARX, ENGELS, 2005, p.56)

Marx, em seu opúsculo tenta demonstrar que a linguagem nada mais é que a materialização produto cerebral, o pensamento, sendo que através dela pode haver o intercâmbio de pensamentos, ideias com os demais homens.

Através do uso da linguagem o homem consegue dar vasão aos seus pensamentos, externando ao mundo seus anseios, podendo atingir um número determinado ou indeterminado de pessoas.

Noam Chomsky diz que a linguagem faz parte de um organismo maduro e complexo, que apresenta um gama de habilidades que permite sua compreensão, sendo assim, se faz, altamente criativa. (Chomsky, Foucault, 2015, p.2)

\begin{abstract}
Toda pessoa que se interessa pelo estudo de línguas depara com um problema empírico bem definido. Ela depara com um organismo, digamos, um organismo maduro, adulto, falante, que, de alguma forma, adquiriu uma fantástica gama de habilidades que lhe permitem, especialmente, se fazer entender, compreender o que as pessoas lhe dizem, e fazer isso de uma forma que penso, podemos chamar de altamente criativa... ou seja, muito daquilo que uma pessoa diz numa comunicação normal como os ouros é novo, muito do que se ouve é original, não tem a menor semelhança com nada que você já experimentou; não se trata, certamente, de um comportamento novo, aleatório, e sim de um comportamento que é - num sentido que é muito difícil de caracterizar - adequado às situações. E, de fato, tem muitas das características daquilo que eu acho que podemos muito bem chamar de criatividade
\end{abstract}

Visto que a comunicação é um processo de intercâmbio de ideias, conhecimento, podendo ter característica uma ou mais pessoas, com a evolução da humanidade alcançou meios massivos de difusão de seus pensamentos.

Em consequência a isto, percebemos que as sociedades vêm sofrendo paulatinamente com a queda de instituições tradicionais, religiões, assim como o enfraquecimento dos laços comunitários, criando assim a massificação dos relacionamentos originados pela comunicação. (CEZAR, 2016, p.525)

Essa destruição dos laços tradicionais das sociedades está intimamente ligada à ideia de globalização, pois tem-se a característica de levar a mesma informação a maior quantidade de 
pessoas, fazendo com que a maior quantidade destas possam entender aquilo que é desejo do comunicador.

E este fenômeno é chamado de massificação da comunicação através da indústria cultural.

\begin{abstract}
Uma vez que nosso foco analítico volta-se para a lógica de produção publicitária, o conceito de Indústria cultural permanece válido, pois, acredita-se que o termo indústria é empregado por Adorno e Horkheimer (1985) como uma metáfora que faz referencia à padronização e à seriação dos bens culturais. $\mathrm{O}$ conceito exprime corretamente o processo de mercantilização cultural e sua atuação nas novas formas de dominação (CAMPOS, 2010, p.28)
\end{abstract}

Diante da massificação a comunicação, assim como a crescente e imensurável difusão de ideias, é que começam a surgir problemas vinculados à boa transmissão dos objetos carregados pela comunicação.

O mundo capitalista cindiu-se entre o material e o intelectual, o objetivo e o subjetivo. Nas fábricas, os processos de produção afastaram o homem do resultado final de seu próprio trabalho. Tarefas repetitivas, mecânicas, o isolaram da participação no todo, pois responsável apenas por uma parte da produção, cabia-lhe meramente a execução de atividades previamente estabelecidas, sem possibilidade de criação. O trabalho alienado é então instituído. Por alienação, entende-se a perda da posse. No conceito de Marx, há uma perda da unidade entre o trabalhador e o produto de seu próprio trabalho, da criação e execução, da produção enquanto expressão singular, característica do sujeito. O trabalho não mais possibilita ao homem o desenvolvimento pleno de sua energia mental e física, ao mesmo tempo em que o produto resultante dele não carrega em si as características do homem que o produziu. A alienação representa a falta de identificação, a perda da conexão e dissolução da unidade entre o homem e sua criação. Essa condição se dá não só pela redução das potencialidades humanas, mas também pela repressão delas. Estabelecese um modo de vida segmentado, como se a vida pudesse ser fracionada sem que seu significado fosse maculado. (MONTEIRO, 2008, p.17)

Feitas as considerações iniciais, devemos partir em direção aos pontos principais deste trabalho, o storytelling. O storytelling, é uma das mais antigas técnicas da humanidade, servindo como meio de transmissão de informações, conhecimento, entretenimento, dominação etc.

Ou seja, diante daquilo que Chomsky e Marx demonstraram, o storytelling, nada mais é que senão, um meio de expressão da linguagem, uma vez que é através dele que o produto da consciência, pensamento e linguagem, que haverá a comunicação.

Hodiernamente, o storytelling tem sido amplamente utilizado por empresas no momento em que pretendem conquistar, e fidelizar clientes. Ocorre que na ânsia de auferir mais lucros, as 
empresas têm apresentado ao mercado de consumo histórias e estórias que são tão sutis que acabam se misturando ou se confundindo com a realidade.

Em muitos casos, o storytelling, tem levado o mercado consumidor a erro, uma vez que muitos têm sido conquistados não por uma imagem visivelmente fantasiosa, mas sim, por contos que se assemelham demasiadamente com a verdade.

\section{O STORYTELLING}

Vivemos numa época onde a transmissão das informações têm grande velocidade, e ocorre através dos mais diversos meios de comunicação desta forma os horizontes do saber cada dia mais tendem a perder seus limites.

As palavras story telling, em tradução livre significa o ato de contar histórias ou estórias. Por isso, o simples ato de narrar contos, fábulas, parábolas, deve ser considerada como uma arte milenar.

\footnotetext{
Ao contar o FATO, o "contante" inclui emoções e daí nasceu a STORY e o TEELING - da story/estória. Story $=0$ fato, a impressão do fato. Telling $=0$ fato recriado através de imagens. Aqui, consideramos aquelas criadas através do alinhamento de sons (palavras).

Para entender o que digo acima é preciso saber a diferença entre duas palavras da língua inglesa: historye story. A primeira está relacionada a fatos reais, como o homem ter chegado à Lua, ou a algum fato que ocorreu na vida alguém. A segunda, é uma Estrutura narrativa, não necessariamente ficção, representando EPISÓDIOS que alinhados, criam a história. Por exemplo, a história de um povo consiste em várias stories, isto é, anedotas, historietas, episódios da vida cotidiana, mitos, etc. (CASTRO, 2013, p.3)
}

Em seguida, Castro (2013) define que Storytelling, é um modelo de comunicação através do qual se conta uma estória utilizando determinadas técnicas organizadas em um processo consciente que possibilita a articulação de informações em um determinado contexto e com um fim desejado.

Para Adilson Xavier o Storytelling, tem três definições, a pragmática, pictórica e poética. Sendo que a primeira deve ser considerada como a tecnarte de elaborar e encadear cenas, apresentando um sentido envolvente que capte a atenção das pessoas ensejando a assimilação de uma ideia central. A segunda, como a tecnarte de moldar e juntar as peças de um quebra- cabeça, formando um quadro memorável. Por fim, a última que consiste na tecnarte de 
empilhar tijolos narrativos, construindo monumentos imaginários repletos de significados. (2105.p.174)

O storyteller, ou seja, aquele que conta a estória, usa as palavras para pintar figuras mentais, lembrando que as palavras sempre causam um grande impacto emocional. (FOR-MUKWAI. 2015. p.279)

O Storytelling age como a síntese do processo de criação e compartilhamento da estória que se encontra dentro de um contexto numa narrativa. É a capacidade de contar e descrever acontecimentos que estão ligados numa estrutura lógica que é capaz de revelar significados àqueles que as ouvem. (CASTRO, 2013, p.10)

Contar histórias é tipicamente atrelado à educação, principalmente à educação básica, onde geralmente são levadas às crianças seus primeiros conceitos, miscigenados numa diversidade de devaneios, visando a facilitação da compreensão.

Apesar de muito comum à educação básica, não podemos deixar de ressaltar que o ato de contar histórias também serve à educação e conscientização de adultos, apenas para ilustrar, podemos citar diversas passagens bíblicas, onde Jesus ensinava seus discípulos através de parábolas, que podem ou não ser fruto de sua imaginação.

\footnotetext{
E Jesus, vendo a multidão, subiu a um monte, e, assentando-se, aproximaram-se dele os seus discípulos;

E, abrindo a sua boca, os ensinava, dizendo:

Bem-aventurados os pobres de espírito, porque deles é o reino dos céus;

Bem-aventurados os que choram, porque eles serão consolados;

Bem-aventurados os humildes, porque receberão a terra por herança;

Bem-aventurados os que têm fome e sede de justiça, pois serão satisfeitos; [...]

(MATEUS, 5:1-6, 2003, p.1623)
}

Sabendo que o ato de contar histórias é uma das mais antigas formas de prender a atenção dos seres humanos, muitas empresas têm aproveitado deste conhecimento para atrair os olhos de seus consumidores para seus produtos e assim conquistá-los.

\footnotetext{
Uma simples estória, pode cercar, fascinar, atrair, provocar, levar o ouvinte à uma explosão de risos, fazer com que ele se sinta no topo do mundo, ou ainda pode atingi-lo de tal forma que lhe possa causar tamanha intimidação que o leve até as lágrimas, bastando saber o quanto a poderosa estória toca o ouvinte. (tradução do autor) (MORRIS, 2014, p. 35)
} 
Para tanto, as agencias de marketing e publicidade têm utilizado as técnicas da storytelling, que significa abordar algum enredo com pequenas narrativas que tragam profundos conceitos, visando dar luz à algum contexto que se pretende abordar. (FONTANA, 2009, p. 6).

Temos a presença do Storytelling quando assistimos novelas, teatros, filmes, e usamos o mesmo quando estamos numa reunião com familiares, amigos ou ainda numa reunião de negócios. (PALACIOS, 2015)

A arte do Storytelling é presente em nossas vidas desde o início da existência humana, sendo que através dela e de suas técnicas, as pessoas passaram ser ativas em suas vidas, expressando suas ideias através das palavras, criando caminhos para estimular a imaginação e o pensamento do ouvinte.

Porém, devido o fato se tratar de contos que podem ser reais ou não, assim que apresentados ao mercado consumidor, pode imediatamente trazer a este confusão entre o sentimento lúdico e o sentimento ludibriado.

Noam Chomsky, diz em sua memorável obra sobre a manipulação através da mídia: "Conduziremos as massas ignorantes para um mundo que elas são estúpidas demais para compreender”. (2014 p.69)

\footnotetext{
O princípio moral imperativo é que a maioria da população é simplesmente estúpida demais para conseguir compreender as coisas. Se tentar participar na administração de seus próprios interesses, só vai causar transtorno. Por essa razão, seria imoral e impróprio permitir que faça isso. Temos de domesticar o rebanho desorientado, impedir que ele arrase, pisoteie e destrua as coisas. É mais ou menos a mesma lógica que diz não ser apropriado deixar uma criança de 3 anos atravessar rua sozinha. Não se dá esse tipo de liberdade a uma criança de 3 anos, porque esta não sabe lidar com ela. Do mesmo modo, não se permite que o rebanho desorientado se torne participante da ação: ele só vai causar transtorno.

Assim, precisamos de algo que domestique o rebanho desorientado, e esse algo é a nova revolução na arte da democracia: a produção do consenso. A mídia, as escolas e a cultura popular têm de ser divididas. Para a classe política e para os responsáveis pela tomada de decisões, elas têm de oferecer uma percepção razoável da realidade, embora também tenham de incutir nele as convicções certas. (CHOMSKY, 2014, p.81)
}

Isto nos leva a perceber que as informações veiculadas através dos sistemas midiáticos, são capazes de constranger as massas à uma prisão intelectual que por conta de sua baixa capacidade cognitiva e reflexiva, dificilmente conseguirão se desvincular. 
Antes de mais nada, devemos lembrar que Storytelling não é apenas uma ferramenta, mas sim um conceito que está presente nas mais diversas atividades humanas.

\footnotetext{
"Storytelling se modela como uma estratégia que influencia determinado público através da história narrada. Vários enfoques podem ser atrelados a essa abordagem, porém para cumprir com os propósitos deste artigo são tratados apenas enfoques estratégicos que circunscrevem o tema. (BORGES,2011, p.109)"
}

Por ser uma ferramenta potente ao alcance das empresas no momento em que buscam conquistar seus clientes, merece que alguns dos seus limites sejam estudados, sob pena de ferir os princípios estipulados no Código de Defesa do Consumidor.

\section{A PUBLICIDADE E O SEU ENVOLVIMENTO NO DIREITO DO CONSUMIDOR. DISTINÇÃO PERTINENTE ENTRE PUBLICIDADE E PROPAGANDA}

Para se alcançar um perfeito enquadramento do tema em estudo é necessária uma compreensão do fenômeno da publicidade e da propaganda em si considerados, enfrentando conceitos e definições próprios dessa área e também aqueles trazidos pelo Código de Defesa do Consumidor. Em verdade, o CDC em suas normas e princípios enfrenta e se preocupa com a publicidade, deixando de lado a propaganda que deverá ser regulada por outra legislação, não pela consumerista.

Ao longo das décadas os termos "publicidade" e "propaganda" foram ganhando sentidos próprios, gerando, algumas vezes, na própria doutrina especializada, certa confusão. Encontra-se na doutrina conceitos diversos sobre publicidade e propaganda, apesar destas expressões muitas vezes serem utilizadas como sinônimo, não significam a mesma coisa. Daí a necessidade de desde já trazer suas definições.

Um conceito geral de publicidade pode ser obtido da disposição do Dicionário da Língua Espanhola, que a define como "a divulgação de noticias ou anúncios de caráter comercial para atraírem possíveis compradores, espectadores, usuários” (Tradução nossa).

Muitos são os conceitos de publicidade trazidos pelos autores da área, porém a maioria com a mesma essência, trazendo a ideia de técnica que se utiliza de textos, palavras, sons e pessoas capazes de exercerem uma ação psicológica sobre determinado público, que passará a consumir produtos e serviços. Aponta Roberto Alfredo Muguillo: 
Em geral, a publicidade, em seu sentido mais amplo, é o ato de comunicação destinado a promover bens e serviços ou facilidades, por qualquer meio, destinados a usuários, consumidores ou clientes de qualquer tipo. Se entende como uma técnica dirigida a atrair a atenção do público para o consumo de bens e serviços e, mais especificamente em uma concepção muito mais rigorosa e concreta. (Tradução nossa) (MUGUILLO, 2005, p.8).

É relevante indicar a percepção do fenômeno da publicidade instituído na Comunidade Europeia, a partir do tratamento dado pela Diretiva 84/450-CEE, do Conselho de 10 de Setembro de 1984, relativa à aproximação das disposições legislativas, regulamentares e administrativas dos Estados-membros em matéria de publicidade enganosa. Em particular, a disposição do artigo $2^{\circ}$ :

Art. $2^{\circ}$ - Na acepção da presente diretiva, entende-se por:

1. Publicidade: qualquer forma de comunicação feita no âmbito duma atividade comercial, industrial, artesanal ou liberal tendo por fim promover o fornecimento de bens ou de serviços, incluindo os bens imóveis, os direitos e as obrigações;

Vale dizer que a própria doutrina especializada utiliza como sinônimos os termos "publicidade" e "propaganda". Tanto assim, que Gino Giacomini Filho (1991, p.15) ao conceituar publicidade diz que: "entende-se por publicidade ou propaganda a forma de comunicação identificada e persuasiva empreendida, de forma paga, através dos meios de comunicação de massa".

Sebastián Capucci aponta efetivamente o núcleo da publicidade, finalidade econômica. Nesse sentido, embora existam diversos conceitos doutrinários produzido percebe-se que:

A totalidade das definições propostas pelos autores, independentemente do seu ponto de vista, é que a publicidade lida com o interesse daqueles que tem uma finalidade econômica clara e que a sua atividade não é corte neutro ou meramente informativo, mas visa a obtenção de benefícios econômicos ou vantagens para aqueles que estão anunciando (Tradução nossa) (CAPUCCI, 2009, p.25).

Partindo para a doutrina jurídica, verifica-se presente no conceito de publicidade a ideia marcante de comercialização. Nesse sentido tem-se o conceito de Antônio Herman Benjamin, que entende por publicidade:

[...] qualquer oferta, comercial e massificada, tendo um patrocinador identificado e objetivando, direta ou indiretamente, a promoção de produtos ou serviços, com utilização de informação e/ou persuasão [...] (BENJAMIN, apud CHAISE, 2001, p.8).

Ainda em termos conceituais, importa apresentar o entendimento de Cláudia Lima Marques, que ratifica a vinculação da publicidade com um objetivo mercadológico. Para a referida autora, pode-se entender como publicidade: 
[...] toda informação ou comunicação difundida com o fim direto ou indireto de promover junto aos consumidores a aquisição de um produto ou utilização de um serviço, qualquer que seja o local ou meio de comunicação utilizado [...] (MARQUES, 2004, p. 470).

Efetivamente, a publicidade na sua essência, sob o enfoque jurídico, visa a captação de consumidores para o fomento do consumo. Roberto Alfredo Muguillo aponta que:

\begin{abstract}
A publicidade, constitui uma atividade fundamental de tráfico econômico jurídico da sociedade, com ampla transcendência sobre esta. Como contrato de colaboração de todo processo econômico e produtivo que a vida moderna faz cada vez mais frequente, encontra sua razão - como vimos - na necessidade de conquistar clientela e abrir mercados para todo tipo de serviço ou produto. É uma forma instrumental, um meio de difusão e captação que o direito, como receptor adequado de todas as exigências da realidade socioeconômica, não pode ignorar. (Tradução nossa) (MUGUILLO, 2005, p.20).
\end{abstract}

O próprio Código Brasileiro de Auto-Regulamentação Publicitária no seu artigo $8^{\circ}$ tratou de definir publicidade como sendo toda atividade destinada a estimular o consumo de bens e serviços, daí identifica-se facilmente o fim de captar consumidores.

A doutrina vem apontando ser desnecessária a distinção entre publicidade e propaganda e que eventual distinção estaria em vias de extinção. Nesse sentido, tem-se o posicionamento de Mauro Salles (apud CAMPOS, 1996, p. 204), para quem haveria apenas de se falar em propaganda, pois tal expressão alcançaria tanto transformações políticas como econômicas. No entanto, manifesta-se também de forma positiva pelo uso da expressão comunicação, pois acredita abranger os dois sentidos - publicidade e propaganda.

Em relação à distinção dos termos publicidade e propaganda, partindo-se da intenção de cada uma, Maria Luiza Campos (1996, p.204) acredita ser difícil separar o ideológico do mercadológico com nitidez, dado a atual complexidade das interações sociais.

\title{
4.1 A PUBLICIDADE NO CÓDIGO DE DEFESA DO CONSUMIDOR
}

O poder das técnicas publicitárias é explicitamente reconhecido; tanto assim que a CRFB/88 tratou no artigo 220, $\S 3^{\circ}$, II, de mencionar a preocupação com a proteção à pessoa e à família em razão da propaganda de produtos, práticas e serviços. Evidencia-se da análise do referido dispositivo que o uso equivocado dos termos não é privilégio da doutrina, haja vista que o próprio texto constitucional no artigo $220, \S 3^{\circ}$. II refere-se à propaganda, quando em verdade deveria mencionar publicidade. 
Poder-se-ia levantar questionamentos no sentido de que a CRFB/88 assegura nos seus arts. $5^{\circ}$, IX e 220, caput, o direito a livre manifestação de pensamento, a criação, a expressão e a informação de qualquer natureza, sendo vedado qualquer tipo de censura e que, de tal forma, não poderia sofrer limitações de normas infraconstitucionais.

Há que se verificar, de logo, que a publicidade não pode ser considerada manifestação de pensamento e nem tão pouco é uma atividade meramente informativa, sua finalidade principal é convencer e estimular o consumo de bens e serviços na sociedade, sendo, portanto, uma técnica que visa induzir ao consumo. Desta forma, há que existir um controle dessa atividade, como o exercido pelo Código de Auto-Regulamentação Publicitária e pelo CDC. Por certo, esses mecanismos de forma alguma ofendem o princípio constitucional que assegura a liberdade na comunicação social.

Evidentemente, os referidos dispositivos constitucionais devem ser analisados em consonância com os arts. $5^{\circ}$, XXXII e 170, V, da Carta Magna, uma vez que a proteção do consumidor pelo Estado é obrigatória. Como entende João Batista de Almeida (2003, p. 114), “o CDC foi fiel ao espírito constitucional na medida em que não faz nenhuma restrição à atividade publicitária e nem promove nenhum tipo de censura, vedando expressamente apenas a publicidade irregular, anormal e prejudicial ao consumidor”.

O CDC inaugurou no ordenamento jurídico um tratamento específico em relação à publicidade, que até então era objeto de auto-regulamentação. Assim, na sociedade atual o estudo do fenômeno da publicidade ganha cada vez mais relevância. Desta forma discorre Felipe Peixoto Braga Netto (2007, p.133) ao verificar que "a publicidade assumiu enorme importância na vida contemporânea. É um mercado que movimenta quantias vultosas. Praticamente não existe, dentre as grandes empresas prestadoras de serviços, aquela que possa existir no mercado sem anunciar".

\section{O STORYTELLING E SEUS REFLEXOS NO DIREITO DO CONSUMIDOR.}

É sabido que as técnicas de storytelling podem ser usadas como armas para conquista de nova porção de consumidores, gerando grandes lucros para os fornecedores. 
Nos dias atuais, o excesso de recursos com infindáveis informações, causa no mercado de consumo grande aborrecimento e enfado, impulsionando uma enorme sensação de tédio, fazendo com que os produtores ou fornecedores de bens da vida, cada vez mais, busquem meios de atrair a atenção de seus consumidores. (XAVIER, 2015. p.253)

O alvo que o storyteller, aquele que conta, narra a estória ou história, busca com todo ímpeto de sua alma esta concentrado na atenção que o receptor da "story" pode lhe conferir, sendo que é por conta desta, a atenção, que os meios de comunicação diuturnamente brigam entre si. A atenção passou ser um dos “ouros” modernos, pois através dela, há a injeção das ideias impostas pelo mercado, assim como o definitivo posicionamento das marcas e produtos.

A conquista da atenção passou a ser diretamente ligada à conquista de mercados e por consequência lucros. Em sequência, cabe destacar relevante citação de Miguel de Unamuno: "Estava certo quem disse que vencer uma batalha é convencer aos seus e aos outros, aos amigos e inimigos, que você a ganhou. Existe uma lenda da realidade que é a substância, a realidade íntima da própria realidade.”. (2015. p.637)

Ocorre que a referida técnica não pode levar o consumidor a acreditar que está consumindo algo porque acreditou profundamente nos contos que a empresa apresentou. Patrícia Weiss bem destaca:

\footnotetext{
Existe uma questão muito importante para se evidenciar e discutir aqui: a ética de conduta das marcas. Depende de como e com qual intenção uma marca utiliza ferramentas de comunicação com alto poder de envolvimento e conexão emocional como o Storytelling ou a Propaganda. A culpa não pode ser atribuída a uma ferramenta - isso seria conveniente e naif demais.

As duas ferramentas podem ser usadas por uma marca para persuadir, seduzir e envolver o consumidor criando uma determinada percepção de imagem na sua mente, mas o risco disso ser baseado em uma mentira existe e sempre existirá. Toda empresa quer ter uma boa imagem, quer ser muito lembrada e precisa vender seus produtos para continuar existindo. Muitas marcas buscam criar uma conexão emocional ainda mais potente com o consumidor através de contagiantes histórias (Storytelling), porque o ser humano, cada vez mais, prefere histórias com começo, meio e fim, com heróis, universos paralelos e menos interrupção e intrusão de mensagens comerciais.

As duas ferramentas de comunicação podem ser "perigosas" se a intenção da marca for distorcida e contar ou prometer uma inverdade. O uso de ficção ou fantasia para se contar de forma mais interessante e engajadora uma verdade, uma questão humana, um conflito, criando um mito a partir do que existe e tem significado para a humanidade, é muito saudável. O cinema, os seriados, a literatura sempre materializaram histórias que capturaram a atenção e provocaram o imaginário da audiência porque conseguiram interpretar mitos, valores e significados da sociedade, de uma cultura.
} 
O Storytelling é uma excelente ferramenta para conectar a emoção das pessoas, ainda mais hoje em dia, quando o consumidor está cada vez mais disperso e impactado por tantas mensagens vendedoras das marcas falando delas mesmas. Mas não é errado, utilizar Storytelling, sobretudo se a marca focar na audiência, no que é realmente relevante e verdadeiro, porque só assim conseguirá gerar forte identificação e credibilidade. Storytelling bem aplicado deve ser utilizado com muita responsabilidade e ética, pois permite criar valor e amplifica o que já tem significado, fazendo sentido porque a história contada foi sobre as pessoas, sobre uma questão humana e verdadeira.’(WEISS, 2015)

Não estamos falando apenas de um conto que faça com que o consumidor tenha empatia com uma empresa, mas sim, de um conto que tira do consumidor a sensação da verdade real. Nesse dizer pondera Adilson Xavier:

Uma vez convincentes os códigos dentro das expectativas tacitamente preestabelecidas entre as partes (autor e público), resta apenas ser consistente. Para efeitos narrativos, se for convincente e consistente, não se discute: é verdade. (XAVIER, 2015. p.728)

Em dezembro de 2014, uma consumidora paulistana se sentiu lesada e denunciou ao CONAR (Conselho Nacional de Auto-regulamentação Publicitária) o que considerava ser publicidade enganosa as informações presentes na embalagem e site do sorvete Diletto.

As informações questionadas pela consumidora, são repletas dos elementos do chamado storytelling, ela relata que o sorvete segue receita formulada por Vittorio, avô do fundador da empresa e que seguiu na profissão depois de emigrar da Itália para o Brasil.

Conta ainda que estas informações são contidas em embalagem e em outras propriedades da Diletto, há fotos de Vittorio e do suposto caminhão usado por ele, bem como o ano em que chegou ao Brasil, além de detalhes da produção do sorvete e das matérias primas empregadas.

Como podemos perceber no presente relato, não se trata de um simples conto, mas sim, se parece demasiadamente com um relato verdadeiro de uma história de família.

Diante disto julgou o relator, o Senhor Conselheiro Eduardo Martins.

[...]há uma questão importante a ser discutida: o nível de detalhes a que desce a construção da Diletto em torno da figura do "avô Vittorio". "A questão mais sensível é o mercado cair no erro de confundir ser lúdico com ludibriante", escreveu. "O encantamento e envolvimento emocional por meio da ludicidade não traz em si a prerrogativa de tentar, com isso, ludibriar as pessoas".

Por isso, o relator votou pela alteração da história presente na embalagem e site da Diletto, retirando as citações ao "avô Vittorio" e sua relação com a fabricação do sorvete, bem como a foto do caminhão dos anos 20. Seu voto foi aprovado por maioria. (CONAR, 2014. Representação 263/14) 
Quando tratamos de publicidade empresarial, o consumerista João Batista de Almeida entende que ela tem três etapas, sendo; informar, sugerir e captar o consumidor, ao passo estas são as intenções do storytelling nas publicidades (ALMEIDA, 2009, p.88).

Tem-se conhecimento de diversos casos de Storytelling ligados a publicidade com o proposito de alcançar o consumidor. A companhia área GOL lançou publicidade contando a história de casais de namorados que mandavam mensagens para serem lidas durante o voo para seus amores no mês dos namorados; a operadora de telefonia VIVO que recriou a história de Eduardo e Mônica, canção de Renato Russo, descrevendo uma história de amor para ao final apontar a importância da comunicação via uso de celular; a coca cola que apresenta a história de pessoas compartilhando o refrigerante; a famosa marca de motocicleta, Harley-Davidson, em passa a história do consumidor que realiza um simples Test Ride e é surpreendido nas ruas da cidade por um grupo de 60 motociclistas pilotando uma motocicleta idêntica a que ele pilota, dentre tantos outros.

Confundir o lúdico com o ludibriante talvez seja a melhor definição para que possamos impor limites ao storytelling. O consumidor, através dos contos apresentados pelo storyteller (quem conta história), não pode ser ludibriado, sendo que o engano do consumidor conforme determina o artigo 37, do Código de Defesa do Consumidor - CDC, é totalmente proibido.

\subsection{O STORYTELLING ILÍCITO NO ÂMBITO DO DIREITO DO CONSUMIDOR}

A publicidade tem se mostrado uma grande aliada do desenvolvimento econômico e do progresso social, detendo como característica marcante o seu poder de persuasão e convencimento do consumidor. Essa importância é reconhecida pelo Direito, que de logo não a inviabiliza, trata apenas de coibir o uso de técnicas que causem danos ao público.

Tanto assim, que o CDC buscou apenas vedar expressamente o uso da publicidade ilícita que pode apresentar-se de duas formas: enganosa e/ou abusiva. Vale acrescentar que nada impede que outras modalidades de publicidade, que de alguma forma violem os preceitos gerais dispostos no CDC, sejam vedadas (FURLAN, 1994, p.114). Seguindo o que fez em diversas passagens do Código, o legislador tratou de conceituar essas publicidades que devem ser evitadas nas relações de consumo. No tocante a esses conceitos João Batista de Almeida tece o seguinte comentário: 


\begin{abstract}
Ao conceituar publicidade enganosa e abusiva, o Código, a contraio sensu, permite uma primeira classificação da publicidade verdadeira e não abusiva, assim entendida aquela que contém dados verdadeiros sobre os elementos do produto ou serviço, não desrespeita valores éticos nem induz o consumidor a se comportar de forma prejudicial ou perigosa à sua saúde ou segurança (ALMEIDA, 2003, p.116, grifos do autor).
\end{abstract}

A ilicitude da publicidade surge da violação dos princípios fundamentais da atividade publicitária, bem como do descumprimento de preceitos legais estabelecidos para regular o fenômeno da publicidade. Nesse sentido, aponta Sebastián Capucci:

Uma publicidade comercial é ilícita quando não cumpre com algum dos três princípios da publicidade comercial e com as disposições legais vigentes que regulam a publicidade de um produto ou serviço. (Tradução nossa) (CAPUCCI, 2009, p.127).

Adverte Raúl Aníbal Etcheverry:

A publicidade, é um veículo ou método muito presente no mercado (para os empresários, para os consumidores e para os outros atores). Se a publicidade não cumpre certos requisitos, pode dar lugar às práticas restritivas ou a distorções que afetem o justo regime e o bem estar que com o mercado livre se querem criar. (Tradução nossa) (ETCHEVERRY, 1997, p.773).

Como não é possível pré-definir todas as modalidades de ilicitudes que podem surgir a partir da publicidade, abordar-se-á, adiante, uma dessas modalidades de ilicitude: enganosidade. O Código de Defesa do Consumidor em seu artigo 37, veda toda publicidade enganosa ou abusiva, não distante o artigo 27 do Código Brasileiro de Auto-regulamentação Publicitária, também proíbe esta pratica lesiva.

A necessidade incontrolável de incentivar práticas consumistas faz com que anunciantes e veículos de comunicação solidariamente faltem com a verdade e divulguem informações falsas, mascaradas, desvirtuadas, enfim, não verdadeiras, para induzir o consumidor à prática de um ato de consumo desnecessário. (BUENO,2014)

A publicidade enganosa destaca-se pela possibilidade de induzir o consumidor em erro no tocante ao objeto da mensagem publicitária. Neste sentido, Rizzatto Nunes (2004, p.465) afirma que "o efeito da publicidade enganosa é induzir o consumidor a acreditar em alguma coisa que não corresponda à realidade do produto ou serviço em si, ou relativamente a seu preço e forma de pagamento, ou, ainda, a sua garantia etc.”.

Há que se verificar que tanto a mentira como o induzimento a erro são elementos que compõem a mensagem enganosa, quer por conter informação falsa, quer por persuadir o público, mas entende-se que a possibilidade de induzimento em erro é o elemento preponderante e indispensável para a caracterização da enganosidade. No entanto, há que se 
perquirir o impacto da enganosidade sobre o consumidor para possível responsabilização dos agentes. Para Maria Luiza Campos (1996, p.226) "a mensagem publicitária pode ser inexata, conter uma mentira, conter um erro, mas ela só ensejará responsabilidade se for passível de induzir o consumidor em erro".

Cabe destacar que qualquer modalidade de informação ou comunicação de caráter publicitário pode sofrer o controle da enganosidade na forma disposta no CDC. Assim, as informações constantes em rótulos e embalagens de produtos, os informativos em relação a serviços e qualquer outra forma de apresentação com finalidade publicitária, também estarão abrangidas pelas disposições do CDC, embora exista divergência doutrinária, como pensa em sentido diverso Luciana Ancona Lopez de Magalhães Dias. Aponta ainda a referida autora que:

\begin{abstract}
A mensagem é publicitária quando apresenta o escopo, direto ou indiretamente, de promover a aquisição de bens ou serviços pelo consumidor. Distingue-se da mera informação que é neutra e desinteressada na apresentação dos dados e características do produto ou serviço como são, por exemplo, as informações de conteúdo jornalístico ou científico. (DIAS, 2010, p.101).
\end{abstract}

Por outro lado, tem-se que apontar que o impacto no consumidor não precisa ser efetivo, ou seja, não há necessidade do consumidor ter sido efetivamente enganado para constatar-se a publicidade enganosa. Valéria Falcão Chaise (2001, p. 33) assevera que "para que a publicidade seja considerada enganosa, basta que potencialmente induza em erro os destinatários, sem necessidade de que tal erro se consume".

Desta forma, passa a concretização do dano a ser irrelevante para a caracterização da publicidade enganosa. Na caracterização da enganosidade não tem qualquer importância a consumação do dano material. "O dano do consumidor é um mero plus (com implicações próprias, notadamente na área penal)" (BENJAMIN apud FURLAN, 1994, p.117).

Ensinam os autores do anteprojeto do CDC(GRINOVER, 2011) que, quando tratamos de questões mercadológicas, não é apenas a publicidade que que acaba se contaminando com práticas enganosas ou lesivas, ensinam que todas as técnicas podem sofrer desvios, trazendo lesões aos consumidores.

Em sequência, esclarecem que o legislador apresentou colossal antipatia pela publicidade enganosa, e percebendo e reconhecendo o dinamismo das técnicas, preferiu conceituar de 
maneira larga aquilo que deveria ser considerado publicidade enganosa, vedando todas e quaisquer possibilidades.

Não há necessidade de que a enganosidade seja real, bastando ser potencial, sendo irrelevante a boa-fé do anunciante. (GRINOVER, 2011, p.343). Há de se ressaltar que o Código Brasileiro de Auto-regulamentação Publicitária, em seu artigo 27, $\S 9^{\circ}$, preferiu ser mais objetivo quando se trata da matéria.

$\S 9^{\circ}$ - Testemunhais

a. O anúncio abrigará apenas depoimentos personalizados e genuínos, ligados à experiência passada ou presente de quem presta o depoimento, ou daquele a quem o depoente personificar;

b. o testemunho utilizado deve ser sempre comprovável;

c. quando se usam modelos sem personalização, permite-se o depoimento como "licença publicitária" que, em nenhuma hipótese, se procurará confundir com um testemunhal;

d. o uso de modelos trajados com uniformes, fardas ou vestimentas características de uma profissão não deverá induzir o Consumidor a erro e será sempre limitado pelas normas éticas da profissão retratada;

e. o uso de sósias depende de autorização da pessoa retratada ou imitada e não deverá induzir a confusão.

Diante do referido dispositivo contido na regulamentação dos atos publicitários, fica caracterizada a possibilidade da utilização do Storytelling, porém, existem limitações, que impedem que o storyteller use artifícios que induza o consumidor ao engano, erro ou confusão.

\section{CONCLUSÃO}

É indiscutível a eficiência e a usabilidade dos recursos de storytelling quando se procura apresentar produtos ou serviços à sociedade e ao mercado consumidor, devendo assim, ser ressaltada sua importância nas relações interpessoais.

Contudo, esta técnica não pode ser apresentada de uma forma que faça com que o consumidor seja conduzido a acreditar em fatos que não são verdadeiros, sob pena de ser caracterizada como publicidade enganosa.

É certo que a prática de storytelling irá mexer com a emoção do consumidor. Todavia, não poderá sobre esse pretex to valer-se da vulnerabilidade do consumidor para alcançar fins ilícitos, quer seja pela enganosidade da mensagem publicitária, quer seja pela sua abusividade. A proteção do consumidor se impõe. 
Portanto, é de crucial importância que o operador do mercado publicitário tenha consigo conhecimentos mínimos, que possam contribuir a não enganosidade de seus trabalhos.

Assim, devemos sempre ter em mente a hipossuficiência e vulnerabilidade do consumidor durante a utilização do Storytelling, para que um simples ato de contar história, não se torne numa tormentosa publicidade enganosa.

\section{REFERENCIAS}

ALMEIDA, João Batista de. Manual de direito do consumidor. 3. Ed. rev. São Paulo. Saraiva, 2009.

BORGES, William José. GOIS, Pedro Henrique. TATTO, Luiz. Storytelling e estratégia: a cognição como forma de integração Revista Saber Acadêmico / Faculdade de Presidente Prudente - v. 11, 2011 - Presidente Prudente: FAPEPE, 2006.

BRAGA NETTO, Felipe Peixoto. Manual de direito do consumidor à luz da jurisprudência do STJ. Salvador: Juspodivm, 2007.

BUENO, Jorge Arbex. Publicidade enganosa. Revista Jus Navigandi, Teresina, ano 19, n. 4150, 11 nov. 2014. Disponível em: <http://jus.com.br/artigos/33697>. Acesso em: 31 jul. 2015 .

CAMPOS, Débora Mendes. A figura da mulher na propaganda: implicações sociais. São Carlos. UFSCAR, 2010.

CAMPOS, Maria Luiza de Sabóia. Publicidade: responsabilidade civil perante o consumidor. São Paulo: Cultural Paulista, 1996.

CAPUCCI, Sebastián. Publicidad comercial. Rosario - AR: Nova Tesis Editorial Jurídica, 2009.

CASTRO, Alfredo Pires de. Storytelling para resultados: como usar estórias no ambiente empresarial. 1. Ed. Qualitymark. 2013.

CEZAR, Thyago. A Propaganda e o acesso à justiça. Juristas do mundo - Obra coletiva. VolIV.Coordenador Prof. Léo da Silva Alves. Ed. Rede. Brasília. 2016.

CHAISE, Valéria Falcão. A publicidade em face do código de defesa do consumidor. São Paulo: Saraiva, 2001.

CHOMSKY, Noam. Mídia política e manipulação. Ed. WMF Martins Fontes. São Paulo. 2014.

CHOMSKY, Noam; FOUCAULT, Michel. Natureza humana - justiça vs poder - o Debate entre Chomsky e Foucault. Ed. WMF Martins Fontes. São Paulo. 2015. 
COMUNICAÇÃO, in Dicionário Priberam da Língua Portuguesa [em linha], 2008-2013, Disponível em http://www.priberam.pt/DLPO/comunica\%C3\%A7\%C3\%A3o>. Acessoem 18 fev.2016.

CONSELHO Nacional de Autorregulamentação Publicitária. Decisão sorvetes Diletto. Relator da decisão Conselheiro Eduardo Martins. Representação 263/14. Disponível em <http://www.conar.org.br/processos/detcaso.php?id=3996> . Acesso em 30 jul. 2015.

DIAS, Lucia Ancona Lopez de Magalhães. Publicidade e direito. São Paulo: Revista dos Tribunais, 2010.

Diccionario de laLenguaEspañola. Real Academia de laLenguaEspañola, Disponível em < www.rae.es. >

ETCHEVERRY, Raúl Aníbal. Publicidad enganosa, competencia y responsabilidad civil in Responsabilidad por dañoseneltercer milênio. Alberto José Bueres. Abeledo-Perrot, Buenos Aires - AR, 1997.

FONTANA, Andrea. Storyselling: strategiedelracconto per vendere se stessi, i propri prodotti, lapropria azienda. Bologna: ETAS, 2010.

FOR-MUKWAI. Gideon F. The Science of storytelling - How to win the hearts and minds of your prospects profit and purpose.AmazonE-book. 2015

FURLAN, Valéria C. P.. Princípio da veracidade nas mensagens publicitárias. Revista de Direito do Consumidor. ${ }^{\circ}$ 10: Revista dos tribunais, 1994.

GIACOMINI FILHO, Gino. Consumidor versus propaganda. São Paulo: Summus, 1991.

GOMES, Raimunda Aline Lucena. A comunicação como direito humano: A comunicação como direito humano. Universidade Federal de Pernambuco. Recife. 2007.

GRINOVER, Ada Pellegrini. Antonio Herman de Vasconcellos e Benjamin; Daniel Roberto Fink. José Geraldo BritoFilomeno. Nelson Nery Junior. ZelmoDenari. Código de defesa do consumidor: comentado pelos autores do anteprojeto. 10 ed. revista, atualizada e reformulada. Vol I. Rio de Janeiro. Forense. 2011.

MARQUES, Cláudia Lima. BENJAMIN, Antônio Herman V. MIRAGEM, Bruno. Comentários ao Código de Defesa do Consumidor. 1 ed. São Paulo: Revista dos Tribunais, 2004.

MATEUS. Bíblia de estudo NVI - Organizador Kenneth Barker. Ed. Vida. São Paulo. 2003

MARX, Karl; ENGELS, Friedrich. A Ideologia Alemã - Feuerbach - A Contraposição entre as Cosmovisões Materialista e Idealista. São Paulo: Martin Claret, 2010.

MONTEIRO, SusiBerbel. A indústria cultural e os meios de comunicação de massaamplificando a persona. Sorocaba. UNISO, 2008. 
MORRIS, Matt. The storytelling Method - Steps to maximize a simple story and make it powerful, inspiring and unforpgettable.Amazon E-book. 2014

NUNES, Luiz Antônio Rizzatto. Curso de direito do consumidor. São Paulo: Saraiva, 2004.

MUGUILlO, Roberto Alfredo. Publicidad. Buenos Aires - AR: Editorial Astrea de Alfredo y Ricardo Depalma, 2005.

PALACIOS, FERNANDO. Caso Hollister: mais uma mentira no Storytelling?. Disponível em <http://www.adnews.com.br/publicidade/caso-hollister-mais-uma-mentira-nostorytelling $>$ Acesso em 30 jul. 2015.

XAVIER, Adilson. Stoytelling - Histórias que deixam marcas. Rio de Janeiro. Adobe Digital Editions. Bestseller. 2015

WEISS, Patrícia. Caso Hollister: mais uma mentira no Storytelling?. Disponível em $<$ http://www.adnews.com.br/publicidade/caso-hollister-mais-uma-mentira-no-storytelling > Acesso em 30 jul. 2015. 